Baldwin, R. W., Price, M. R., and Robins, R. A. (1972). Nature New Biology, 238, 185.

Cooksley, W. G. E., et al. (1972). Australian and New Zealand Fournal of Medicine, 3,261 .

Currie, G. A., and Basham, C. (1972). British fournal of Cancer, 62, 427.

Finch, S. C., and Finch, C. A. (1955). Medicine, 34, 381.

Halliday, W. J., and Miller, S. (1972). International fournal of Cancer, 9, 477. Halliday, W. J., Maluish, A., and Isbister, W. H. (1974 a). British fournal of Cancer. 29, 31.

Halliday, W. J., Maluish, A., and Miller, S. (1974 b). Cellular Immunology. In press.

Hellström, K. E., and Hellström, I. (1974). Advances in Immunology, 18. In press.

Hellström, I., Hellström, K. E., Sjögren, H. O., and Warner, G. A. (1971 a). International fournal of Cancer, $7,1$.

Hellström, I., Sjögren, H. O., Warner, G. A., and Hellström, K. E. (1971 b). International fournal of Cancer, 7, 226.
Jagarlamoody, S. M. Aust, J. C. Tew, R. C., and McKhann, C. F. (1971). Proceedings of the National Academy of Sciences, 68, 1346.

Maluish, A., and Halliday, W. J. (1974). Fournal of the National Cancer Institute. In press.

Peterson, M. R., Barker, L. F., and Schade, D. S. (1973). Vox Sanguinis,

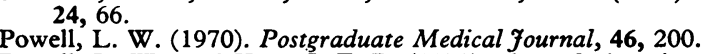

Powell, L. W., and Kerr, J. F. R. (1970). Australasian Annals of Medicine, $19,1$.

Segall, A., Weiler, O., Genin, J., Lacour, J., and Lacour, F. (1972). International fournal of Cancer, 9, 417.

Sjögren, H. O., Hellström, I., Bansal, S. C., and Hellström, K. E. (1971). Proceedings of the National Academy of Sciences, 68, 1372.

Sjögren, H. O., Hellström, I., Bansal, S. C., Warner, G. A., and Hellström, K. E. (1972). International Fournal of Cancer, 9, 274.

Stillman, A., and Zamcheck, N. (1970). American fournal of Digestive Diseases, 15, 1003 .

Vanky, F., Stjernswärd, J., Klein, G., and Nilsonne, U. (1971). Fournal of the National Cancer Institute, 47, 95.

\title{
Energy Provision, Tissue Utilization, and Weight Loss in Prolonged Starvation
}

\author{
J. RUNCIE, T. E. HILDITCH
}

British Medical fournal, 1974, 2, 352-356

\section{Summary}

Daily weight loss measurements in 76 fasting, obese patients ( 58 females, 18 males) have shown a characteristic pattern of rapid loss initially (up to day 14) followed by a slower but uniform reduction in weight. There were significant sex differences. Measurements of tissue breakdown showed that the initial rapid weight loss was due to the continuing utilization by the nervous system of glucose derived from lean tissue. This requirement fell noticeably from the second week of starvation. Irreversible fluid elimination also contributed to the initial phase of rapid weight loss. Fat remained the primary source of energy throughout starvation and in established fasting (more than 14 days) contributed $96 \%$ of that requirement.

\section{Introduction}

Many obese patients can undergo prolonged starvation and lose large amounts of weight (Drenick et al., 1964; Thomson et al., 1966; Runcie and Thomson, 1970). Under these conditions the rate of weight loss is greatest initially and thereafter falls off (Rapoport et al., 1965). It has been suggested that weight loss in starvation results from the breakdown of lean rather than adipose tissue (Benoit et al., 1965). We have reviewed the weight loss responses in 76 fasting, obese patients (58 females and 18 males) throughout extended starvation to define the normal response. Since there are no large carbohydrate

University Department of Geriatric Medicine, Stobhill General Hospital, Glasgow G21 3UW

J. RUNCIE, M.B., M.R.C.P., Consultant Physician, (Formerly Lecturer in Materia Medica)

Department of Clinical Physics and Bioengineering, Western Regional Hospital Board, Whole Body Monitor Unit, Southern Gegional Hospital Board,

T. E. HILDITCH, B.sc., Senior Physicist reserves in the body metabolic energy needs can be met only by the catabolism of fat in adipose tissue or protein in lean body mass or of some combination of these two-the metabolic "fuel mix." In this study breakdown of lean tissue was measured continuously throughout fasting in a number of patients as either total protein degradation (urinary nitrogen excretion) or urinary potassium loss to provide a continuous measure of the varying proportions of lean tissue and fat metabolized. These values were also used to calculate the mean energy production of fasting, obese subjects.

\section{Patients and Methods}

The patients' obesity was either massive or refractory to treatment or they suffered from serious intercurrent disease aggravated by obesity. Before fasting all patients received a normal ward diet. The therapeutic regimen consisted simply of no food. Water-soluble vitamins (Multivite tablets) were the only supplements allowed. Water was not restricted. Patients adopted their own level of physical activity. No attempt was made to measure energy utilization direct, primarily because of the long starvation periods employed. Patients were weighed daily after rising and emptying the bladder. The urine of 35 patients was collected continuously throughout fasting and an aliquot of each 24-hour specimen was analysed for its potassium content by a standard flame photometer technique. In 28 patients (18 females and 10 males) urinary nitrogen excretion was measured by a macroKjeldahl method incorporating a multidistillation apparatus.

In seven females changes in whole-body potassium throughout starvation were measured by a scanning type of wholebody monitor. The machine is housed in a custom-built steel room. It consists of a ring of six sodium iodide detectors, three above and three below the patient. Each detector is $15 \mathrm{~cm}$ in diameter and $10 \mathrm{~cm}$ in depth. An estimation takes 44 minutes. Calibration data, principally to take account of the differences in absorption of radiation by subjects of varying size and body thickness, were obtained by extensive studies with ${ }^{40} \mathrm{~K}$-filled phantoms. Water-filled bags were used to simulate varying thicknesses of adipose tissue. The results were similar to the calibration data of Cohn and Dombrowski (1970) for a monitor of comparable detector geometry and are shown in fig. 1. The standard deviation for each estimate of total body potassium, including statistical and calibration errors, was $4 \%$. 


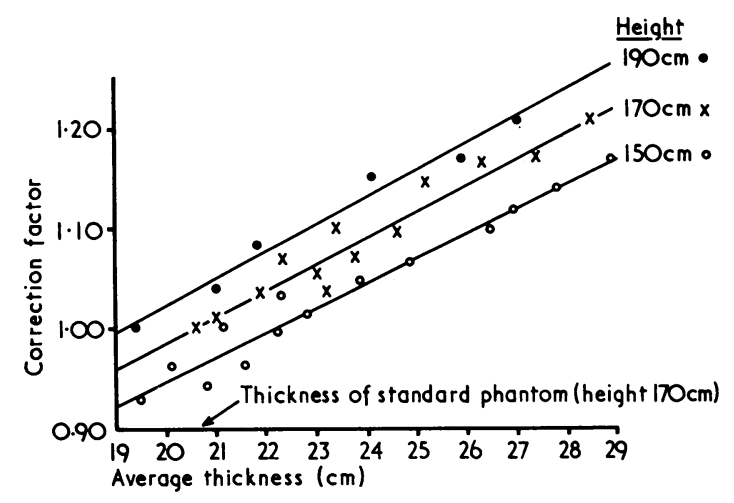

FIG. 1-Whole-body potassium calibration data derived from studies with ${ }^{40} \mathrm{~K}$-filled phantoms. Varying thicknesses of adipose tissue were simulated by means of water-filled bags.

\section{Results}

\section{WEIGHT LOSS}

To facilitate presentation and analysis of data and comparison of results weight loss up to day 30 of starvation is considered. This period divided into two phases, 1 to 14 days and 15 to 30 days, to separate the initial phase of rapid weight loss and the later, slower weight loss of established starvation. The choice of day 14 to divide these phases is slightly arbitrary in that the transition commonly occurs between days 4 and 8 of starvation but in some patients occurs later than day 8 and in a few occurs before day 4 . In all cases the transition had taken place by day 14 . Males and females were analysed separately (table I).

During days 1 to 14 the mean weight loss ( \pm 2 S.E.) was significantly greater in males $(10.2 \pm 0.9 \mathrm{~kg})$ than in females $(7.7 \pm 0.5 \mathrm{~kg})(P<0.001)$. This was largely attributable to the greater initial weight of males. But when this effect was removed by considering percentage weight losses this difference $(8.3 \pm 0.5 \%$ for males; $7 \cdot 4 \pm 0.4 \%$ for females) remained significant $(P<0.01)$. In established starvation (more than 14 days) the mean weight losses between days 15 and 22 and 23 and 30 were similar for males and females, showing that the normal response was one of a linear loss of weight in this period. There were, however, wide individual variations on this pattern. This was most apparent in females, some of whom showed a stepwise weight loss. These differences are thought to be due to variable but reversible water retention by the kidneys. In the extreme form this may be manifested as periodic oedema.

Weight loss data can alternatively be expressed by plotting the mean daily weights, as shown in fig. 2 . Each value is expressed

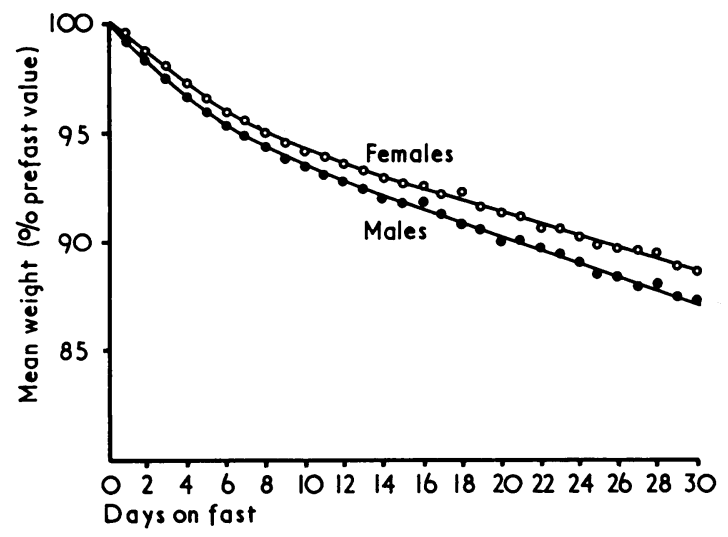

FIG. 2-Mean daily weight of patients during starvation exposed as percentage of weight before fasting. as a percentage of the mean weight for the group before fasting. The best-fit curve to the data is in each case linear after 14 days $(r=0.965$ for males and 0.96 for females), with a slope ( \pm 2 S.E.) of $0.3 \pm 0.046 \% /$ day for males and $0.26 \pm 0.025 \% /$ day for females. The difference in percentage weight loss in established starvation between the sexes is not significant $(P>0 \cdot 10)$. When the absolute mean weight loss in this period $(0.37 \pm 0.046$ $\mathrm{kg}$ /day for males; $0.27 \pm 0.03 \mathrm{~kg} /$ day for females) is considered the difference between the sexes is significant $(P<0.001)$.

TABLE I-Pattern of Weight Loss in 76 Fasting Subjects

\begin{tabular}{|c|c|c|c|c|c|c|c|c|}
\hline \multirow{3}{*}{$\begin{array}{l}\text { Case } \\
\text { No. }\end{array}$} & \multirow{3}{*}{$\begin{array}{c}\text { Age } \\
\text { (Years }\end{array}$} & \multirow{3}{*}{$\begin{array}{c}\text { Prefast } \\
\text { Wt. } \\
\text { (kg) }\end{array}$} & \multicolumn{4}{|c|}{ Weight Loss } & \multirow{2}{*}{\multicolumn{2}{|c|}{ 23-30 Days }} \\
\hline & & & \multicolumn{2}{|c|}{ 1-14 Days } & \multicolumn{2}{|c|}{ 15-22 Days } & & \\
\hline & & & kg & $\%$ & kg & $\%$ & kg & $\%$ \\
\hline \multicolumn{9}{|c|}{ Female Patients } \\
\hline $\begin{array}{r}1 \\
2 \\
3 \\
4 \\
5 \\
6 \\
7 \\
8 \\
9 \\
10 \\
11 \\
12 \\
13 \\
14 \\
15 \\
16 \\
17 \\
18 \\
19 \\
20 \\
21 \\
22 \\
23 \\
24 \\
25 \\
26 \\
27 \\
28 \\
29 \\
30 \\
31 \\
32 \\
33 \\
34 \\
35 \\
36 \\
37 \\
38 \\
39 \\
40 \\
41 \\
42 \\
43 \\
44 \\
45 \\
46 \\
47 \\
48 \\
49 \\
50 \\
51 \\
52 \\
53 \\
54 \\
55 \\
56 \\
57 \\
58\end{array}$ & $\begin{array}{l}18 \\
53 \\
59 \\
34 \\
58 \\
30 \\
45 \\
40 \\
17 \\
42 \\
47 \\
19 \\
16 \\
14 \\
46 \\
29 \\
39 \\
30 \\
33 \\
34 \\
45 \\
28 \\
34 \\
41 \\
29 \\
34 \\
16 \\
17 \\
40 \\
52 \\
42 \\
49 \\
31 \\
36 \\
35 \\
37 \\
47 \\
34 \\
22 \\
44 \\
29 \\
40 \\
61 \\
57 \\
54 \\
57 \\
52 \\
61 \\
58 \\
52 \\
51 \\
55 \\
71 \\
56 \\
62 \\
55 \\
25 \\
55\end{array}$ & $\begin{array}{r}105 \cdot 2 \\
112.7 \\
109.4 \\
98.3 \\
109.2 \\
134.3 \\
95.0 \\
117.2 \\
90.3 \\
101.1 \\
89.6 \\
107.6 \\
94.7 \\
82.7 \\
119.9 \\
98.9 \\
90.7 \\
111.7 \\
86.3 \\
100.4 \\
102.8 \\
93.5 \\
114.4 \\
82.5 \\
127.6 \\
122.1 \\
92.7 \\
99.3 \\
119.0 \\
94.9 \\
129.5 \\
95.1 \\
93.1 \\
136.3 \\
99.7 \\
117.8 \\
153.2 \\
142.1 \\
105.1 \\
138.9 \\
78.5 \\
105.6 \\
86.7 \\
80.8 \\
124.7 \\
93.8 \\
93.5 \\
101.6 \\
107.7 \\
83.1 \\
117.4 \\
118.9 \\
74.9 \\
89.4 \\
86.8 \\
81.9 \\
127.3 \\
106.2\end{array}$ & 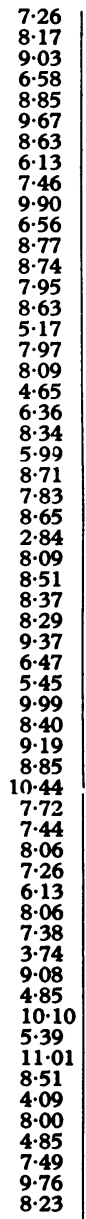 & 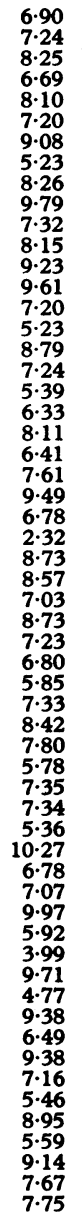 & $\begin{array}{l}2.92 \\
1.96 \\
2.27 \\
1.25 \\
3.06 \\
3.09 \\
1.90 \\
3.04 \\
2.92 \\
2.61 \\
3.92 \\
1.08 \\
2.56 \\
2.38 \\
2.33 \\
1.79 \\
1.09 \\
0.99 \\
3.12 \\
0.45 \\
3.35 \\
1.82 \\
1.73 \\
0.74 \\
1.90 \\
1.36 \\
5.45 \\
2.84 \\
0.82 \\
2.30 \\
2.16 \\
1.93 \\
1.93 \\
2.04 \\
2.16 \\
0.29 \\
2.04 \\
1.36 \\
2.95 \\
2.95 \\
0.20 \\
1.82 \\
2.33 \\
1.14 \\
1.45 \\
1.82 \\
3.18\end{array}$ & $\begin{array}{l}2.88 \\
2.19 \\
2.11 \\
1.32 \\
3.70 \\
2.58 \\
1.92 \\
3.35 \\
2.61 \\
3.02 \\
3.90 \\
1.05 \\
2.74 \\
2.88 \\
1.83 \\
1.47 \\
2.04 \\
1.00 \\
2.62 \\
0.47 \\
2.59 \\
1.91 \\
1.86 \\
0.54 \\
1.90 \\
1.15 \\
3.56 \\
2.00 \\
0.78 \\
1.65 \\
2.75 \\
1.83 \\
2.23 \\
2.52 \\
1.73 \\
0.31 \\
2.18 \\
1.34 \\
\\
2.51 \\
0.17 \\
2.43 \\
2.61 \\
1.31 \\
1.77 \\
1.43 \\
2.99\end{array}$ & $\begin{array}{l}2.61 \\
1.59 \\
2.61 \\
1.50 \\
2.72 \\
2.41 \\
\\
1.88 \\
2.27 \\
1.73 \\
2.95 \\
2.61 \\
2.41 \\
2.22 \\
2.75 \\
0.68 \\
2.90 \\
1.82 \\
\\
2.61 \\
2.07 \\
1.50 \\
3.12 \\
3.12 \\
1.48 \\
2.98 \\
1.19 \\
1.68 \\
1.48 \\
5.17 \\
2.04 \\
4.09 \\
1.59 \\
1.39 \\
1.90 \\
2.07 \\
1.11 \\
2.72 \\
2.22 \\
2.95 \\
2.47 \\
\\
2.78 \\
1.19 \\
1.59 \\
2.33 \\
1.14 \\
1.93 \\
2.50 \\
0.57\end{array}$ & $\begin{array}{l}2.48 \\
1.41 \\
2.38 \\
1.52 \\
2.02 \\
2.54 \\
\\
1.86 \\
2.53 \\
1.61 \\
3.11 \\
3.15 \\
2.01 \\
2.24 \\
3.03 \\
0.61 \\
2.89 \\
1.77 \\
\\
3.16 \\
1.62 \\
1.23 \\
3.14 \\
2.62 \\
156 . \\
2.30 \\
1.25 \\
1.80 \\
1.08 \\
5.18 \\
1.73 \\
2.67 \\
1.12 \\
1.32 \\
1.37 \\
1.96 \\
1.28 \\
2.18 \\
2.37 \\
3.15 \\
2.43 \\
\\
2.36 \\
1.00 \\
2.12 \\
2.61 \\
1.31 \\
2.36 \\
1.96 \\
0.54\end{array}$ \\
\hline $\begin{array}{l}\text { Mean } \\
\text { S.D. }\end{array}$ & & $\begin{array}{c}104.7 \\
17.63\end{array}$ & $\begin{array}{l}7.68 \\
1.74\end{array}$ & $\begin{array}{l}7.41 \\
1.61\end{array}$ & $\begin{array}{l}2.17 \\
0.94\end{array}$ & $\begin{array}{l}2.09 \\
0.85\end{array}$ & $\begin{array}{l}2.18 \\
0.84\end{array}$ & $\begin{array}{l}2.08 \\
0.83\end{array}$ \\
\hline \multicolumn{9}{|c|}{ Male Patients } \\
\hline $\begin{array}{l}59 \\
60 \\
61 \\
62 \\
63 \\
64 \\
65 \\
66 \\
67 \\
68 \\
69 \\
70 \\
71 \\
72 \\
73 \\
74 \\
75 \\
76\end{array}$ & $\begin{array}{l}22 \\
26 \\
55 \\
49 \\
53 \\
44 \\
46 \\
29 \\
31 \\
39 \\
30 \\
25 \\
26 \\
46 \\
66 \\
48 \\
51 \\
56\end{array}$ & $\begin{array}{r}113.7 \\
126.2 \\
132.2 \\
75.8 \\
105.8 \\
108.3 \\
112.6 \\
117.1 \\
144.0 \\
111.5 \\
86.3 \\
122.4 \\
129.3 \\
123.9 \\
114.5 \\
184.3 \\
199.3 \\
115.0\end{array}$ & \begin{tabular}{r|}
9.71 \\
9.85 \\
12.95 \\
6.92 \\
8.74 \\
7.89 \\
8.17 \\
9.40 \\
12.00 \\
11.90 \\
8.17 \\
10.40 \\
10.65 \\
10.00 \\
9.20 \\
12.90 \\
12.70 \\
11.45
\end{tabular} & $\begin{array}{r}8 \cdot 54 \\
7.80 \\
9.79 \\
9 \cdot 13 \\
8.26 \\
7 \cdot 28 \\
7.25 \\
8.03 \\
8.33 \\
10.67 \\
9 \cdot 47 \\
8.50 \\
8.24 \\
8.07 \\
8.03 \\
7.00 \\
6.37 \\
9.96\end{array}$ & $\begin{array}{l}3.29 \\
3.58 \\
1.90 \\
2.78 \\
3.50 \\
3.18 \\
3.20 \\
3.17 \\
3.63 \\
3.90 \\
2.45 \\
1.95 \\
3.63 \\
1.36 \\
3.76\end{array}$ & $\begin{array}{l}2.89 \\
2.84 \\
2.51 \\
2.57 \\
3.11 \\
2.71 \\
2.22 \\
2.84 \\
4.21 \\
3.19 \\
1.89 \\
1.70 \\
1.97 \\
0.68 \\
3.27\end{array}$ & $\begin{array}{l}3 \cdot 29 \\
2 \cdot 80 \\
1 \cdot 16 \\
3 \cdot 12 \\
2 \cdot 40 \\
3 \cdot 24 \\
3.40 \\
2 \cdot 30 \\
3 \cdot 18 \\
3.50 \\
3 \cdot 60 \\
2 \cdot 80 \\
3 \cdot 40 \\
1 \cdot 70 \\
2 \cdot 80\end{array}$ & $\begin{array}{l}2.89 \\
2.22 \\
1.53 \\
2.88 \\
2.13 \\
2.77 \\
2.36 \\
2.06 \\
3.68 \\
2.86 \\
2.78 \\
2.44 \\
1.84 \\
0.85 \\
2.43\end{array}$ \\
\hline $\begin{array}{l}\text { Mean } \\
\text { S.D. }\end{array}$ & & $\begin{array}{l}123 \cdot 4 \\
29 \cdot 44\end{array}$ & $\begin{array}{r}10.17 \\
1.84\end{array}$ & $\begin{array}{l}8 \cdot 30 \\
1 \cdot 10\end{array}$ & $\begin{array}{l}3.02 \\
0.77\end{array}$ & $\begin{array}{l}2.57 \\
0.82\end{array}$ & $\begin{array}{l}2 \cdot 84 \\
07 \cdot 0\end{array}$ & $\begin{array}{l}2.38 \\
0.67\end{array}$ \\
\hline
\end{tabular}




\section{PROTEIN DEGRADATION}

Protein degradation was measured direct in 28 subjects (18 females and 10 males) as daily urinary nitrogen excretion (fig. 3 ). The mean daily nitrogen output ( \pm 2 S.E.) in females and males on day 1 was $9 \cdot 45 \pm 0 \cdot 8$ and $11 \cdot 7 \pm 1 \cdot 2 \mathrm{~g}$ respectively. On day 30 the respective values were $4 \cdot 2 \pm 0 \cdot 8$ and $3 \cdot 6 \pm 0 \cdot 6 \mathrm{~g}$.

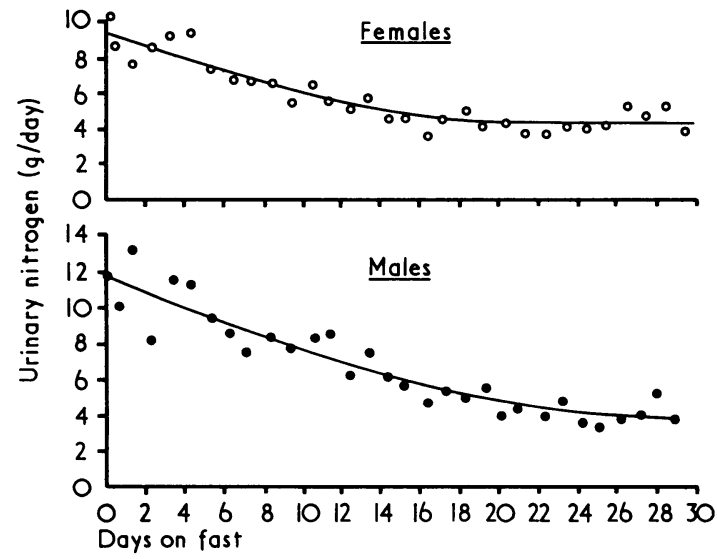

FIG. 3-Mean daily nitrogen excretion during starvation in 18 female and 10 male patients.

\section{Urinary Potassium Excretion}

Urinary potassium excretion was measured in 35 subjects (25 females and 10 males) (fig. 4). The mean daily loss ( \pm 2 S.E.) for females and males on day 1 was $35 \cdot 3 \pm 3 \cdot 2$ and $37 \cdot 2$ $\pm 5.0 \mathrm{mEq}$ respectively. The respective values on day 30 were $14.5 \pm 3.2$ and $16.5 \pm 3.2 \mathrm{mEq}$. The mean ( \pm 2 S.E.) cumulative potassium loss in females over this period was $635 \pm 102 \mathrm{mEq}$.



FIG. 4-Mean daily potassium excretion during starvation in 25 female and 10 male patients.

\section{WHOLE-BODY POTASSIUM CHANGES}

Whole-body potassium changes were measured in seven females over days 1 to 30 (table II). When recorded as a percentage of the prefast value (fig. 5) the best-fit curve to the data yields a value for the mean ( \pm 2 S.E.) cumulative potassium loss in females of $502 \pm 100 \mathrm{mEq}$ over days 1 to 30 . This does not differ significantly from the value of $635 \pm 102 \mathrm{mEq}$ found by direct measurement of urinary potassium loss $(P>0.05)$.

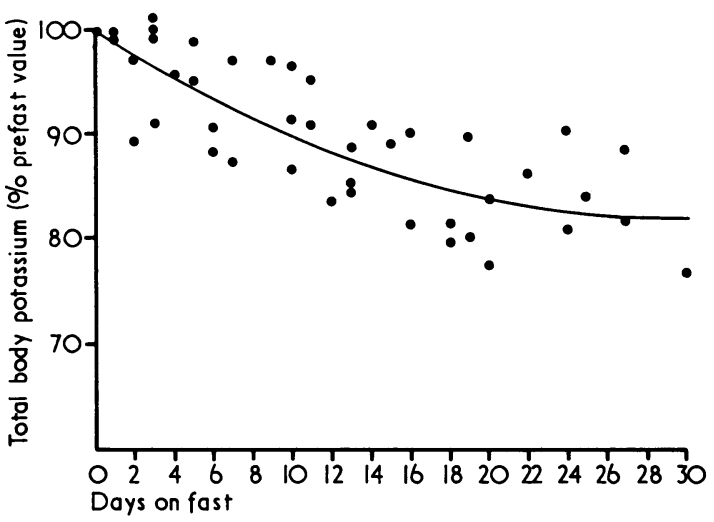

FIG. 5-Mean daily whole-body potassiun content during starvation expressed as percentage of value before fasting.

TABLE II-Changes in Whole-body Potassium (mEq) in 7 Women during Starvation

\begin{tabular}{|c|c|c|c|c|c|c|c|}
\hline \multirow{2}{*}{$\begin{array}{l}\text { Day } \\
\text { of } \\
\text { Fast }\end{array}$} & Case 1 & Case 2 & Case 3 & Case 4 & Case 5 & Case 6 & Case 7 \\
\hline & $\begin{array}{c}105.2 \mathrm{~kg} \\
162.0 \mathrm{~cm} \\
18 \mathrm{yr}\end{array}$ & $\begin{array}{c}112.7 \mathrm{~kg} \\
152 \cdot 3 \mathrm{~cm} \\
53 \mathrm{yr}\end{array}$ & $\begin{array}{c}109.4 \mathrm{~kg} \\
147.0 \mathrm{~cm} \\
59 \mathrm{yr}\end{array}$ & $\begin{array}{c}98 \cdot 3 \mathrm{~kg} \\
157 \cdot 2 \mathrm{~cm} \\
34 \mathrm{yr}\end{array}$ & $\begin{array}{c}109 \cdot 2 \mathrm{~kg} \\
156.3 \mathrm{~cm} \\
58 \mathrm{yr}\end{array}$ & $\begin{array}{c}134 \cdot 3 \mathrm{~kg} \\
160 \cdot 5 \mathrm{~cm} \\
30 \mathrm{yr}\end{array}$ & $\begin{array}{c}95.0 \mathrm{~kg} \\
153.0 \mathrm{~cm} \\
45 \mathrm{yr}\end{array}$ \\
\hline $\begin{array}{r}0 \\
1 \\
2 \\
3 \\
4 \\
5 \\
6 \\
7 \\
8 \\
9 \\
10 \\
11 \\
12 \\
13 \\
14 \\
15 \\
16 \\
17 \\
18 \\
19 \\
20 \\
21 \\
22 \\
23 \\
24 \\
25 \\
26 \\
27 \\
28 \\
29 \\
30\end{array}$ & $\begin{array}{l}2,610 \\
2,634 \\
2,289 \\
2,210 \\
2,166 \\
\\
2,072 \\
2,059 \\
2,033\end{array}$ & $\begin{array}{l}2,634 \\
2,570 \\
2,583 \\
2,608\end{array}$ & $\begin{array}{r}2,519 \\
2,560 \\
2,200\end{array}$ & $\begin{array}{l}2,749 \\
2,634 \\
2,480 \\
2,506 \\
2,301\end{array}$ & $\begin{array}{l}2,110 \\
2,301\end{array}$ & $\begin{array}{l}2,657 \\
2,634 \\
2,462 \\
2,442\end{array}$ & $\begin{array}{l}2,557 \\
2,480 \\
2,531 \\
2,519 \\
2,480 \\
2,416 \\
2,173\end{array}$ \\
\hline
\end{tabular}

\section{Analysis}

\section{LEAN TISSUE DEGRADATION}

Measurements of urinary nitrogen loss can be readily converted to the amount of lean tissue degradation. Lean tissue was strictly defined as a fat-free, non-bony tissue containing $25 \%$ protein and $75 \%$ water (Kinney et al., 1970). It is basically protein with its water of hydration. Degradation of $1 \mathrm{~kg}$ of lean tissue will yield $40 \mathrm{~g}$ of urinary nitrogen (since $1 \mathrm{~g}$ of urinary nitrogen is equivalent to $6.25 \mathrm{~g}$ of protein degraded) and is assumed to result in a weight loss of $1 \mathrm{~kg}$. To obtain the mean lean tissue breakdown ( $\mathrm{kg} /$ day) daily urinary nitrogen excretion ( $\mathrm{g} /$ day) is divided by 40 . This value is recorded for females and males over days 1 to 30 in fig. 6 and shows that lean tissue breakdown for females on day 1 of starvation was $0.24 \mathrm{~kg}$ and on day $300.1 \mathrm{~kg}$. The comparable values for males were 0.29 and $0.09 \mathrm{~kg}$. Comparable values for lean tissue degradation can 
be indirectly calculated from urinary potassium excretion. For this purpose the potassium content of lean tissue, as defined here, is taken to be $130 \mathrm{mEq} / \mathrm{kg}$, based on published data on the concentration of potassium in muscle cells (Graham, 1970). From the values of lean tissue breakdown shown in fig. 6 the potassium yield would be $34 \mathrm{mEq}$ on day 1 , if the data for both sexes are combined, and on day 30 the value would be $13 \mathrm{mEq}$. These agree closely with the observed values of 36 and $15 \mathrm{mEq}$ in this study.

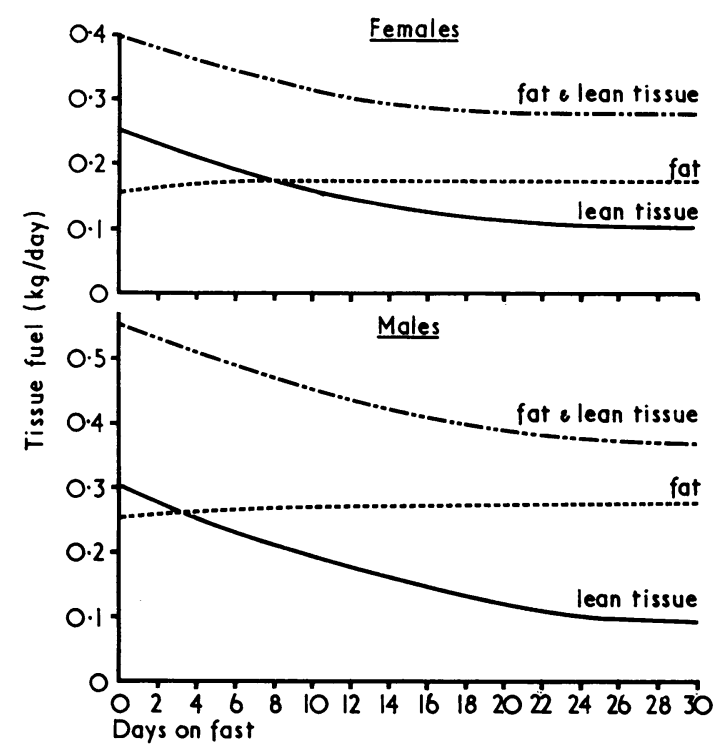

FIG. 6-Mean daily breakdown of lean tissue and fat in prolonged starvation.

\section{FAT BREAKDOWN}

The magnitude of fat breakdown can be calculated as the difference between total weight loss (fig. 2) and the amount of lean tissue breakdown, provided that no irreversible fluid shifts have occurred and that fat oxidation is complete. When applied to weight loss in established starvation acceptable values of fat breakdown are obtained. For example, on day 30 the mean fat breakdown for females was $0.17 \mathrm{~kg}$ and for males $0.28 \mathrm{~kg}$. Since lean tissue contains $25 \%$ protein and terminal combustion of protein yields $4 \mathrm{kcal} / \mathrm{g}$ the energy yield of lean tissue is $1 \mathrm{kcal} / \mathrm{g}$. The corresponding value for fat is $9.3 \mathrm{kcal} / \mathrm{g}$. Hence on day 30 estimated energy production from tissue catabolism is 1,680 kcal for females and 2,690 kcal for males.

When this calculation is applied to the phase of rapid weight loss (days 1 to 14) the values obtained for the magnitude of fat breakdown are clearly erroneous unless there is a reduction of some $50 \%$ in the efficiency of fat oxidation in this period. This would be an unreasonable assumption. If it can be assumed that energy requirements are relatively constant throughout starvation, and this has been shown in established starvation, a simple relation can be used to measure fat breakdown in that at any point $(t)$ in starvation $9,300 W_{p}(t)+1,000 W_{L}(t)=$ $2,690 \mathrm{kcal}$ for males or $1,680 \mathrm{kcal}$ for females where $W_{F}$ and $W_{L}$ are the weights of fat and lean tissue catabolized on any day $t$.

Substitution of the appropriate values of $W_{L}(t)$ allows $W_{F}(t)$ to be calculated. In fig. 6 the mean measured values of lean tissue breakdown siarvation and the derived values for fat breakdown are plotted for males and females. These results show the primacy of fat as the energy source throughout fasting. On day 1 fat provided $88 \%$ of the energy requirements and on day $3095 \%$.

Integration of the data in fig. 6 shows that the contribution of lean tissue and fat breakdown to total weight loss during days
1 to 14 was $6.8 \pm 0.8 \mathrm{~kg}$ in males and $4.7 \pm 0.6 \mathrm{~kg}$ in females. The observed weight losses, however, were $10.2 \pm 0.9$ and $7.7 \pm 0.5$ $\mathrm{kg}$ respectively. The excess losses of $3.4 \pm 1.2 \mathrm{~kg}$ in males and $3.0 \pm 0.8 \mathrm{~kg}$ in females can be accounted for only by irreversible fluid loss in this period.

\section{Discussion}

Though there are wide variations among obese patients in the amount of weight lost over a period of starvation this study shows that weight loss usually conforms to a typical and highly reproducible pattern (fig. 2). The biphasic nature of weight loss was not apparent in early studies because the fasting periods never exceeded 14 days (Bloom, 1959; Duncan et al., 1962). At the outset weight loss is a complex effect resulting from breakdown of lean tissue (hydrated protein), utilization of body fat, and elimination of some 3 to 51 . of body fluid. In established starvation (more than 14 days) the rate of weight loss is less but virtually constant and is due solely to the catabolism of lean tissue and fat.

The results (fig. 6) show that protein is never a significant source of energy at any point in starvation. Its comparatively large-scale catabolism in the initial period of fasting is due to a continuing dependence of the central nervous system on proteinderived glucose as a metabolic substrate (Cahill et al., 1966). The subsequent switch of nervous tissue to direct utilization of the products of fat breakdown reduces body demand for glucose. The metabolic needs of those tissues, such as the red cell and the adrenal medulla, which remain obligatorily glycolytic can be met largely by glucose synthesis de novo from carbon fragments by the liver and kidney (Felig et al., 1969). Though it has been shown that the enzymes necessary for ketone body dissimilation are present widely and in high concentration throughout the brain (Page and Williamson, 1971) the factors which promote this change are not known. A better understanding of this mechanism raises the intriguing possibility that the prognosis in brain-damaged subjects might be improved if this change in cerebral substrate utilization could be effected.

Obesity is a heterogeneous disease complex showing social bias in women and a correlation with alcoholism in men

(Goldblatt et al., 1965). Further evidence of this heterogeneity can be inferred from table I. There were significant sex differences in weight loss but, in addition, in males the response was more uniform, as shown by their smaller standard deviations. During days 1 to 14 eight females (14\%) lost less than $5{ }^{\varsigma} 5 \%$ of their prefast weight. By contrast the least weight lost by males in this period was $6.3 \%$, and this was in the heaviest subject. This difference was maintained in established starvation. Energy is required for basal metabolism, a relatively constant requirement, and physical activity. Since all patients adopted their own level of physical activity this finding suggests that obesity in some females, more so than in males, may be due to an abnormally low level of spontaneous activity. This variant of obesity would require a different therapeutic approach. In grossly obese patients (over $100 \mathrm{~kg}$ ) a related phenomenon may be observed. In many, after marked but variable weight loss is achieved the rate of weight loss increases, suggesting that a real increase in spontaneous activity has occurred. Such a response would explain, at least in part, the refractory nature of gross obesity and underlines the need to promote meaningful weight loss in such subjects.

In clinical practice the characteristic weight loss responses in fasting obese patients has two important advantages. In established starvation failure to maintain a uniform weight loss has proved a sensitive indicator of surreptitious eating. When it occurs this results in an obvious pattern of randomly interspersed weight gains when individual weight losses are charted. Secondly, this effect can be used to predict weight loss at any point in established starvation, a factor which is often helpful in maintaining morale. 
We wish to thank Dr. T. J. Thomson, University Department of Materia Medica, Stobhill General Hospital, for his permission to study patients under his care. Mr. P. S. Waldie and the staff of the department of audio visual services at Stobhill General Hospital prepared the tables and illustrations.

\section{References}

Benoit, F. L., Martin, R. L., and Watten, R. H. (1965). Annals of Internal Medicine, 63, 604

Bloom, W. L. (1959). Metabolism, 8, 214 .

Cahill, G. F., et al. (1966). fournal of Clinical Investigation, 45, 1751.
Cohn, S. H., and Dombrowski, C. S. (1970). Fournal of Nuclear Medicine, $11,239$.

Drenick, E. J., Swendsied, M. E., Blahd, W. H., and Tuttle, S. G. (1964). fournal of the American Medical Association, 187, 100.

Duncan, G. G., Jenson, W. K., Frazer, R. I., and Cristofari, F. C. (1962). Fournal of the American Medical Association, 181, 309.

Felig, P., Owen, O. E., Wahren, J., and Cahill, G. F. (1969). Fournal of Clinical Investigation, 48, 584.

Goldblatt, P. B., Moore, M. E., and Stunkard, A. J. (1965). Fournal of the American Medical Association, 192, 1039.

Graham, J. A. (1970). Lancet, 1, 386.

Kinney, J. M., Duke, J. H., Long, C. L., and Gump, F. E., (1970). Fourna of Clinical Pathology, 23, Suppl. No. 4, p. 65.

Page, M. A., and Williamson, D. H. (1971). Lancet, 2, 66.

Rapoport, A., From, G. L. A., and Husdan, H. (1965). Metabolism, 14, 31

Runcie, J., and Thomson, T. J. (1970). British Medical fournal, 3, 432

Thomson, T. J., Runcie, J., and Miller, V. (1966). Lancet, 2, 992.

\section{Long-term Follow-up of Therapeutic Starvation}

\author{
J. A. INNES, \\ I. W. CAMPBELL, \\ C. J. CAMPBELL, \\ A. L. NEEDLE, J. F. MUNRO
}

British Medical fournal, 1974, 2, 356-359

\section{Summary}

A total of 75 grossly obese patients were admitted to hospital for 80 episodes of prolonged starvation. Five took their own discharge within two weeks of admission and 12 defaulted from follow-up within 12 months of discharge. The others were all followed up for periods of 12 to 64 months. Altogether 39 episodes in 34 patients were classified as failures, eight as modified successes, and 16 as successes, though five of the latter patients subsequently defaulted. Success was associated with regular follow-up attendance but could not be otherwise predicted. A number of patients obtained tangible benefit from starvation despite a subsequent gain in weight.

\section{Introduction}

Starvation is an effective method of weight reduction but entails lengthy periods of stay in hospital and is not withour risk. It can be justified only if there is a pressing need for temporary weight loss or if the long-term results are superior to those obtained with conventional treatment. Previous experience had suggested that prolonged inpatient starvation might be of permanent value if patients were reduced to within $25 \%$ in excess of their ideal weight (Munro et al., 1970). We describe here the further follow-up of 75 patients with refractory obesity after fasting.

\section{Patients and Methods}

All the patients had failed to make satisfactory progress while attending an obesity clinic, had expressed the desire to be

\section{Eastern General Hospital, Edinburgh}

J. A. INNES, M.B., M.R.C.P., Registrar

I. W. CAMPBELL, M.B., M.R.C.P., Senior House Officer (Now Registrar in General Medicine, Royal Infirmary, Edinburgh)

J. F. MUNRO, M.B., F.R.C.P., Consultant Physician

Edenhall Hospital, Musselburgh, Midlothian

C. J. CAMPBELL, M.B., M.R.C.P., Senior House Officer (Now Registrar, Diabetic Department, Royal Infirmary, Edinburgh) A. L. NEEDLE, M.B., B.S., Senior House Officer (Present address: Western admitted to hospital for starvation, and were willing to remain in hospital until reduced to within $25 \%$ in excess of their ideal weight. Altogether 27 were male patients with an average age of 30 years (range 14 to 53 years) and 48 were female patients with an average of 29 years (range 15 to 57 years). They were admitted to a hospital with good rehabilitative facilities and began the starvation regimen after a short assessment period. The emphasis throughout was on trust rather than supervision and many admitted to periodic cheating. Initially a low-energy, carbohydrate-restricted meal was provided if specifically requested and many took one such meal a week. This offer was subsequently withheld but in other respects the regimen as previously described was followed (Munro et al., 1970).

Five patients (three women and two men) discharged themselves within a week or so and are excluded from further analysis. The mean admission weight of the remaining 45 women was $75.3 \%$ (range 41 to $141 \%$ ) in excess of their ideal weight and that of the 25 men $77.5 \%$ (range 45 to $123 \%$ ) in excess of their ideal weight.

At the completion of fasting patients were re-fed in hospital for four to seven days and offered further dietary advice. During follow-up the policy was to see them at intervals of four weeks or less. They were given every encouragement to lose weight and they and their close relatives had the opportunity of attending a monthly "group" session held during and after starvation. Many were treated with anorectic drugs, four wene readmitted for starvation, and 11 underwent funther shont periods of outpatient fasting. The patients were subdivided according to sex, percentage in excess of their ideal weight at the time of admission, and whether or not they reduced to within $25 \%$ in excess of their ideal weight at the completion of fasting. The following criteria were applied to evaluate the outcome of treatment: default, default from the clinic within 12 months of discharge and without subsequent reattendance; failure, a gain of $15 \mathrm{~kg}$ or of $50 \%$ of the total weight lost during starvation; modified success, a gain of 10 to $15 \mathrm{~kg}$ or of 33 to $50 \%$ of the total weight lost during starvation; success, a gain of less than $10 \mathrm{~kg}$ and less than $33 \%$ of the weight lost. Patients followed for at least 12 months but who then failed to attend were classified as "successes," "modified successes," or "failures," with subsequent default.

Results

During a mean fast of 14 weeks the mean weight loss was $29.6 \mathrm{~kg}$, but only 39 patients, including four of the $12 \mathrm{most}$ 